Journal of Educational Research in Developing Areas (JEREDA)

Vol. 2. Issue 2, Pp. 183-195, 2021

http://www.jeredajournal.com

E-mail: info@jeredajournal.com

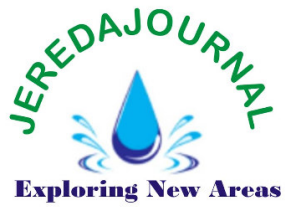

Mini Review DoI:https://doi.org/10.47434/JEREDA. eISSN:2735-9107

\title{
SCHOOL ENVIRONMENT ON SOCIAL DEVELOPMENT OF STUDENTS WITH HEARING IMPAIRMENT IN BASSA, PLATEAU STATE, NIGERIA
}

\author{
${ }^{1}$ Patricia Kwalzoom Longpoe, ${ }^{2}$ Nenrot V. Gomwalk \\ ${ }^{1,2}$ Department of Special Education \& Rehabilitation Sciences, University of Jos. Nigeria \\ Email: ${ }^{1}$ pklongpoe@gmail.com \\ (i)https://orcid.org/0000-0002-8768-0119
}

Received: $1^{\text {st }}$ March, 2021; Revised: $16^{\text {th }}$ May, 2021; Accepted: $21^{\text {st }}$ July, 2021

\begin{abstract}
Introduction: The school environment is a learning place where the students learn and interact with learning facilities to socialize and face the challenges of society.

Purpose: This study was carried out to evaluate on impact of school environment on social development of children with hearing impairment in School for the Deaf, Bassa, Plateau State.

Methodology: The study was carried out with the use of questionnaires from fifty respondents as a data collection method. The sample drawn from the population for the study consists of students from students in School for the Deaf, Bassa, Plateau State. The data collected through this medium were analyzed using simple percentage and discussed with explanations.

Results: The study find out Children's social behaviours depend on several factors both human and physical environment. Classroom teachers and parents greatly contribute to children's social behaviours, limited access to both students and teachers to reading materials, school building quality, and lack of a good library have a great influence on student social development.
\end{abstract}

Recommendations: It is recommended that adequate classroom building, wellequipped library and other schools facilities should be provided in the school to help promote students social development.

Keywords: School environment, social development, hearing impairment

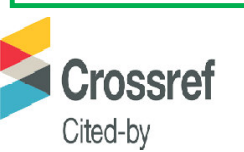

\section{Cite paper as:}

Longpoe, P. K., \& Gomwalk, N. V. (2021). School environment on social development of students with hearing impairment in Bassa, Plateau state, Nigeria. Journal of Educational Research in Developing Areas, 2(2), 183-195. https://doi.org/10.47434/JEREDA.2.2.2021.183.

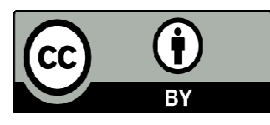

Copyright (c) 2021 The author(s) of this article retain(s) the copyright.

\section{PUBLIC INTEREST STATEMENT}

The findings of this study would be of immense benefit to governments as policy makers, in formulating effective planning and implementation policies and programs for improving school academic activities for people with hearing impairment. It would also provide policy makers with intelligent forecast and analysis of future needs of the schools in the areas of building and facilities. Special school heads will have the opportunity to improve in school supervision to ensure quality teaching and learning in special schools. The findings would enable teachers to appreciate the need for a proper instructional delivery. It would help the special teachers to improve both in teaching effectiveness and increased productivity in the schools. 
Journal of Educational Research in Developing Areas (JEREDA)

Vol. 2. Issue 2, Pp. 183-195, 2021

http://www.jeredajournal.com

E-mail: info@jeredajournal.com

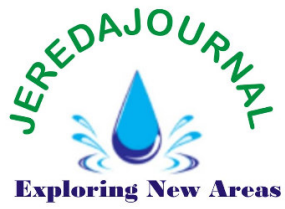

\section{INTRODUCTION}

Generally in the whole world, particularly in Nigeria, education has been considered to be the cornerstone of development. It forms the basis for literacy, skill acquisition, technological advancement and ability to harness human and material resources towards the achievement of societal goal (FME, 2004). Education is very important in any given society. It is a process by which the abilities and capabilities of an individual are developed. These abilities might be physical abilities, emotional abilities, social abilities and intellectual abilities. It is the actualization of human potential so that the individual can become something more than what he was before. According to Ugwuanyi (2003) education is the process by which society establishes to assist the young to learn and understand the heritage of the past, participate productively in the society and contribute meaningfully for the development of the society. Education as a process by which any society through schools, colleges, universities and other institutions deliberately transmits knowledge, values and skills from one person to another. As a result of deregulation in Nigerian education, the system of education has two main interest groups - public education and private education. Public education is the pillar or backbone of society that opens the door to equal educational opportunity for all citizens. It is a public-owned property that attracts public attention constantly.

According to Akpa, Udoh and Faghamiye (2005), environment can be defined as a system within which living organisms interact with the physical element while education environment is a learning place where the learner learn and interact with learning facilities in order to be socialized and face the challenges in the society. Murad (2012) sees environments as consisting of all elements existing around man and which exert some influence on him. These include physical, biological and social attributes. Environment can also be seen as aggregate of all the external condition and influence affecting the life and development of an organism.

The environment plays a very important role in one's personal growth. A healthy environment creates a perfect individual while the environment is a less healthy environment that produces a problematic society. Over the past three decades, students' discipline and behavioural problems often occur. Hoffman, Hutchinson, and Reiss (2009) conclude that a positive social environment has been linked to improving students' behaviour; it also has a positive impact on the formation of attitudes and behaviours of students in many key areas such as making decisions, equality and justice, caring, sensitivity, and discipline of a student.

Therefore, the environment is a contributing factor to student delinquency, such as loitering, playing truant, bullying, skipping, etc. Adolescent stage is a transition stage from childhood to adulthood. Their emotions and minds will easily change according to the environment. The existence of internet cafes and various entertainment centres and others that provide a variety of products that can promote illicit social ills. It gives positive impact on formation of students' behaviour in developing essential soft skills like making decisions, love for social justice and equality as well as nurturing caring nature, sensitivity and shaping the discipline. Human behaviours and shaped based on what they observe in the surrounding environment. Therefore, bad and problematic behaviours are the result of negative environment (Murad, 2012;Ani, 2016).

In recent years, there has been an increasing amount of literature on the social environment. Problematic habits and behaviours are formed as the result of what a person or an individual leaves from his environment. The changes in behaviour, may evolve according to the environment. The environment can serve as a powerful tool to shape the behavioural learning processes of an individual (Aldridge, Mcchesney, \& Afari, 2018). Ironically speaking, humans create an environment system and learn from it which also includes negative 
Journal of Educational Research in Developing Areas (JEREDA)

Vol. 2. Issue 2, Pp. 183-195, 2021

http://www.jeredajournal.com

E-mail: info@jeredajournal.com

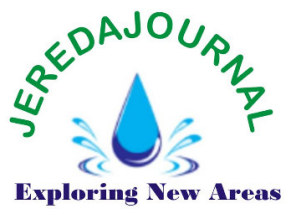

elements that shape the youngsters behaviours. This is due to the immature state of their thinking faculty and lack of life experience. Both of these elements trigger behavioural problems. Therefore these physiological attributes of these children, teenagers and young adults are making them vulnerable to the negative effects of media and environment (Afari, 2015).

In addition, most student misconduct is due to hanging out. A student who likes to hang out is vulnerable to environmental influences and leads to various misconduct such as smoking, drug abuse, steal and so on. $" 165,000$ criminal cases recorded in 2005, about 14,000 criminal cases were conducted involving students. Another study found that social environment factors became the major contributor to student behaviour (Midgley, 2014).

The theories presented suggest that if students are too vulnerable to factors that risk their inclination to become delinquent is high (Turner et al., 2009; Aldridge et al., 2017). This behavioural problem is found in a risky social environment and school atmosphere that often interacts with other factors affecting deviant behaviour (Farrel \& Flannery 2005). Other studies have shown consistent, findings on the relationship between the rate of drug intake and the increased risk involved in misconduct among students (Ismail, Ghazalli and Ibrahim, 2015).

From a personal point of view, as developed by the Maturation theory of substance use theory by Haley \& Baryza (1990) concludes that material retrieval in childhood is a result of stress or misery $\mathrm{n}$ their environment, leading to using material to control his behaviour (Erol, \& Orth, 2011). The environmental and socio-demographic environment as above has confirmed that most detainees who are trained have low levels of education, have no fixed and unemployed jobs (Vuchinich, 2007).

Social environment factors can influence and become a source of learning in the process of formulating behaviour through various patterns of social learning (Azhar, 2006). This is

because humans naturally mimic, whether imitating in a positive or negative direction (Umaruddin, 2003). The environment can affect the appreciation of the individual's moral values. Appreciation of moral values is the final stage of the social convergence process formed through social learning that incorporates elements of social learning fundamental elements such as stimulus, reaction, affirmation, compliance, identification, modeling and impersonation. The environment plays an important role in the formation of individual identity and behaviour. This role involves significant individuals such as parents, family members, peers, teachers and mass media. It has a strong influence in the formation of each individual's identity (Zakaria, et al., 2012).

Hearing is the ability of the ear to receive and interpret sound or message. Hearing impairment is therefore the inability of the sense organ (ear) to receive and interpret deprivation that has been noted to hinder the afflicted persons' development in general. Hearing impairment as viewed by Ojile (2006) is a generic term indicating a hearing inability which may range in degree of severity from mild to profound. In line with Ojile's definition, Okeke (2001) further explained hearing impairment as a generic term used to qualify anyone with hearing loss. It is a degree of hearing loss that can range from minimal hearing loss to profound deafness. Ojile and Okeke's definition has similarities with the explanation given by the Conference of Executives of the American School for the Deaf (Obi, 2006), which described hearing impairment as a generic term indicating a hearing disability that can range in severity from mild to profound. This also includes subset of deaf and hard of hearing.

In the same line of thought, Olawale (2000) argued that children with hearing impairment are those who have lost some, but not all of their hearing and who can or cannot benefit from the use of hearing aids in order to understand the use of speech. Corroborating this, Abang (2005) affirms that children with hearing 
Journal of Educational Research in Developing Areas (JEREDA)

Vol. 2. Issue 2, Pp. 183-195, 2021

http://www.jeredajournal.com

E-mail: info@jeredajournal.com

impairment are those children with slight hearing loss, mild hearing loss, and moderate hearing loss, severe to profound hearing loss. Similarly, Lowerfield (2013) argued that hearing impairment or hearing loss implies a disability category label of individuals who require special education and related services to function and achieve relative achievement in academic and other life endeavours. In another study, Abang (2005) agreed with others that hearing impairment is in a continuum ranging from mild to profound.

\section{STATEMENT OF THE PROBLEM}

The problem under study has to do with an unsatisfactory condition of the educational system being operated in Nigeria. The establishment of government schools/community schools has resulted in a situation whereby some schools were favoured in terms of the provision of rich environment than others. It has been very difficult, if not impossible, for the government to standardize the school environment. Thus the environment varies from school to school. Some schools have adequate school buildings, good library and suitable textbooks, good administrative management, professionally qualified teachers, good laboratory equipments as well as good location. While in some schools little or none of these exist. It is because of this that Chike-Okoli (2004) in line with Ikediashi (2002) have pointed out that inadequate or poor physical infrastructure and unsatisfactory building design are likely to cause some physical discomfort for the students and are therefore bound to influence their social development.

\section{PURPOSE OF THE STUDY}

The main objective of the study was to determine the influence of the school environment on the social development of students with hearing impairment in the School for the Deaf, Bassa, Plateau State. Specifically, the study intended to:

1. investigate to what extent the quality of the physical school environment with respect to

school buildings affects the social development of children with hearing impairment in the School for the Deaf, Bassa, Plateau State.

2. determine the extent the library services affects social development of students of children with hearing impairment in School for the Deaf, Bassa, Plateau State.

3. find out to what extent the location of the school affects the social development of children with hearing impairment in the School for the Deaf, Bassa, Plateau State.

4. determine to what extent school facilities affect social development of children with hearing impairment at the School for the Deaf, Bassa, Plateau State.

\section{RESEARCH QUESTIONS}

The following research questions guided the study:

1. to what extent do the qualities of the physical school environment with regard to school building affect the social development of children with hearing impairment?

2. to what extent do library services affect the social development of children with hearing impairment?

3. how does the location of the school affect the social development of children with hearing impairment?

4. to what extent do school facilities affect the social development of students of children with hearing impairment?

\section{METHODOLOGY \\ Research Design}

The researcher adopted descriptive survey research design to gather data. The research aims to investigate the 'impact of the school environment on the social development of children with hearing impairment in the School for the Deaf, Bassa, Plateau State.

\section{Population and Sample}

The target populations of the study were all students with hearing 
Journal of Educational Research in Developing Areas (JEREDA)

Vol. 2. Issue 2, Pp. 183-195, 2021

http://www.jeredajournal.com

E-mail: info@jeredajournal.com

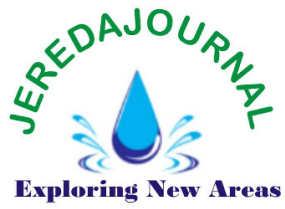

impairment between the ages of 11 and 25 of the School for the Deaf, Bassa, Plateau State. The researchers will adopt random sampling techniques where Fifty (50) students with hearing impairment will be randomly selected from and SSS 1-3 classes, twenty students from SS1 (10 Males and 10 females), SS2 (10 Males and 10 females) and SS3 (5 Males and 5 females) from School for the Handicapped from school in Bassa Local Government Area.

\section{Instrument for Data Collection}

The research instrument to be used is a structured questionnaire. The questionnaire is made up of two sections. Section ' $A$ ' dealt with personal information of the respondent which include the age, class, and sex of the respondents, while the section $B$ in the questionnaire for the students contained twenty (20) structured questions which were drafted from the research questions of the topic in order to find out the "impact of school environment on social development children with hearing impairment in School for the Deaf, Bassa, Plateau State. The questionnaire was carefully constructed, developed and structured by the researcher. It was then submitted to the supervisor for assessment and corrections before the final administration of the items in questionnaire.

\section{Procedure for Data Collection}

This research work was carried out by administering a questionnaire to each of the students with hearing impairment selected in the selected secondary school in Bassa, Plateau state and collecting after it has been completed correctly. The researchers give out questionnaire to fifty students in the selected secondary schools asking them to fill in correctly and collect after filling out questionnaire.

\section{Method of Data Analysis}

The questionnaire collected from the students was analyzed. The descriptive statistics frequency distribution percentage, mean and standard deviation were employed to analyze the information collected in the study. The responses of the participants were presented and analyzed using frequency tables and percentages as appropriate.

\section{RESULTS}

Research Question 1: To what extent do the qualities of the physical school environment with regard to school building affect the social development of children with hearing impairment?

Table 1: Analysis of extent of qualities of the physical school environment

\begin{tabular}{|c|c|c|c|c|c|c|c|c|}
\hline & ITEMS & & & $A$ & SD & $D$ & Mean & $\overline{S D}$ \\
\hline 1 & $\begin{array}{l}\text { Healthy and attractive school } \\
\text { environment influence the socio } \\
\text { development of children with hearing } \\
\text { impairment in School for the Deaf, } \\
\text { Bassa, Plateau State }\end{array}$ & 27 & 16 & 5 & & 2 & 3.36 & 1.83 \\
\hline 2 & $\begin{array}{l}\text { Active interactive with the school } \\
\text { environment develop the intellect of } \\
\text { children with hearing impairment in } \\
\text { School for the Deaf, Bassa, Plateau } \\
\text { State }\end{array}$ & 15 & 25 & 9 & & 1 & 3.08 & 1.74 \\
\hline 3 & $\begin{array}{l}\text { Unconducive school environment } \\
\text { affects the children with hearing } \\
\text { impairment in the school for the Deaf, } \\
\text { Bassa, Plateau State }\end{array}$ & 21 & 9 & 19 & & 1 & 3.00 & 1.73 \\
\hline
\end{tabular}


Journal of Educational Research in Developing Areas (JEREDA)

Vol. 2. Issue 2, Pp. 183-195, 2021

http://www.jeredajournal.com

E-mail: info@jeredajournal.com

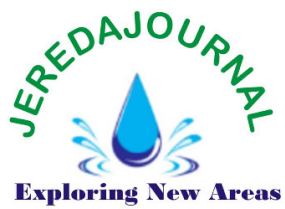

From Table 1 , item 1 has the mean of 3.36, which is more than 2.5 and it should be accepted that a healthy and attractive school environment influences the socio-development of children with hearing impairment in School for the Deaf, Bassa, Plateau State. Item 2 has the mean of 3.08 which is more than 2.5 and it is to be accepted that Active Interactive with the School Environment Develops the Intellect of Children with Hearing Impairment in School for the Deaf,

Bassa, Plateau State. Item 3 has the mean of 3.00 which is more than 2.5 and it is to be accepted that unconducive school environment affects the children with hearing impairment in School for the Deaf, Bassa, Plateau State.

Research Question 2: To what extent do the library services affect the social development of children with hearing impairment?

Table 2: Analysis of the Extent of Library Services

\begin{tabular}{|c|c|c|c|c|c|c|c|c|}
\hline & ITEMS & & & $\boldsymbol{A}$ & $S D$ & $D$ & Mean & SD \\
\hline 1 & $\begin{array}{l}\text { School without well-equipped library } \\
\text { affects the socio-development of } \\
\text { children with hearing impairment in } \\
\text { School for the Deaf, Bassa, Plateau } \\
\text { State }\end{array}$ & 22 & 14 & 9 & & 5 & 3.06 & 1.74 \\
\hline 2 & $\begin{array}{l}\text { Encouragement of children with } \\
\text { hearing impairment to read in the } \\
\text { library affects their socio } \\
\text { development in School for the Deaf, } \\
\text { Bassa, Plateau State }\end{array}$ & 11 & 21 & 15 & & 3 & 2.80 & 1.67 \\
\hline 3 & $\begin{array}{l}\text { Does good quality of library services } \\
\text { affect the socio development of } \\
\text { children with hearing impairment in } \\
\text { School for the Deaf, Bassa, Plateau } \\
\text { State }\end{array}$ & 20 & 12 & 12 & & 6 & 2.92 & 1.70 \\
\hline 4 & $\begin{array}{l}\text { The library is a center of balanced } \\
\text { diet that improves the socio- } \\
\text { development of children with hearing } \\
\text { in School for the Deaf, Bassa, Plateau } \\
\text { State }\end{array}$ & 9 & 19 & 18 & & 4 & 2.66 & 1.63 \\
\hline
\end{tabular}

From Table 2, item 1 has the mean of 3.06 which is more than 2.5 and it is to be accepted that School without well- equipped library affect the socio development of children with hearing impairment in School for the Deaf, Bassa, Plateau State.Item 2 has the mean of 2.80 which is more than 2.5 and it is to be accepted that encouragement of children with hearing impairment to read in the library affect their socio development in School for the Deaf, Bassa, Plateau State. Item 3 has the mean of 2.92 which is more than 2.5 and it is to be accepted that Does good quality of library services affect the socio development of children with hearing impairment in School for the Deaf, Bassa, Plateau State. Item 4 has the mean of 2.66 which is more than 2.5 and it should be accepted that the Library is a center of balanced diet that improves the sociodevelopment of children with hearing in the School for the Deaf, Bassa, Plateau State.

Research Questions 3: How does school location affect social development of children with hearing impairment? 
Journal of Educational Research in Developing Areas (JEREDA)

Vol. 2. Issue 2, Pp. 183-195, 2021

http://www.jeredajournal.com

E-mail: info@jeredajournal.com

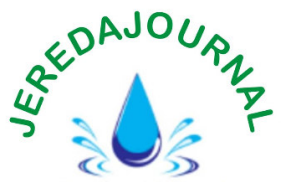

Exploring New Areas

Table 3. Analysis of School location on socio development.

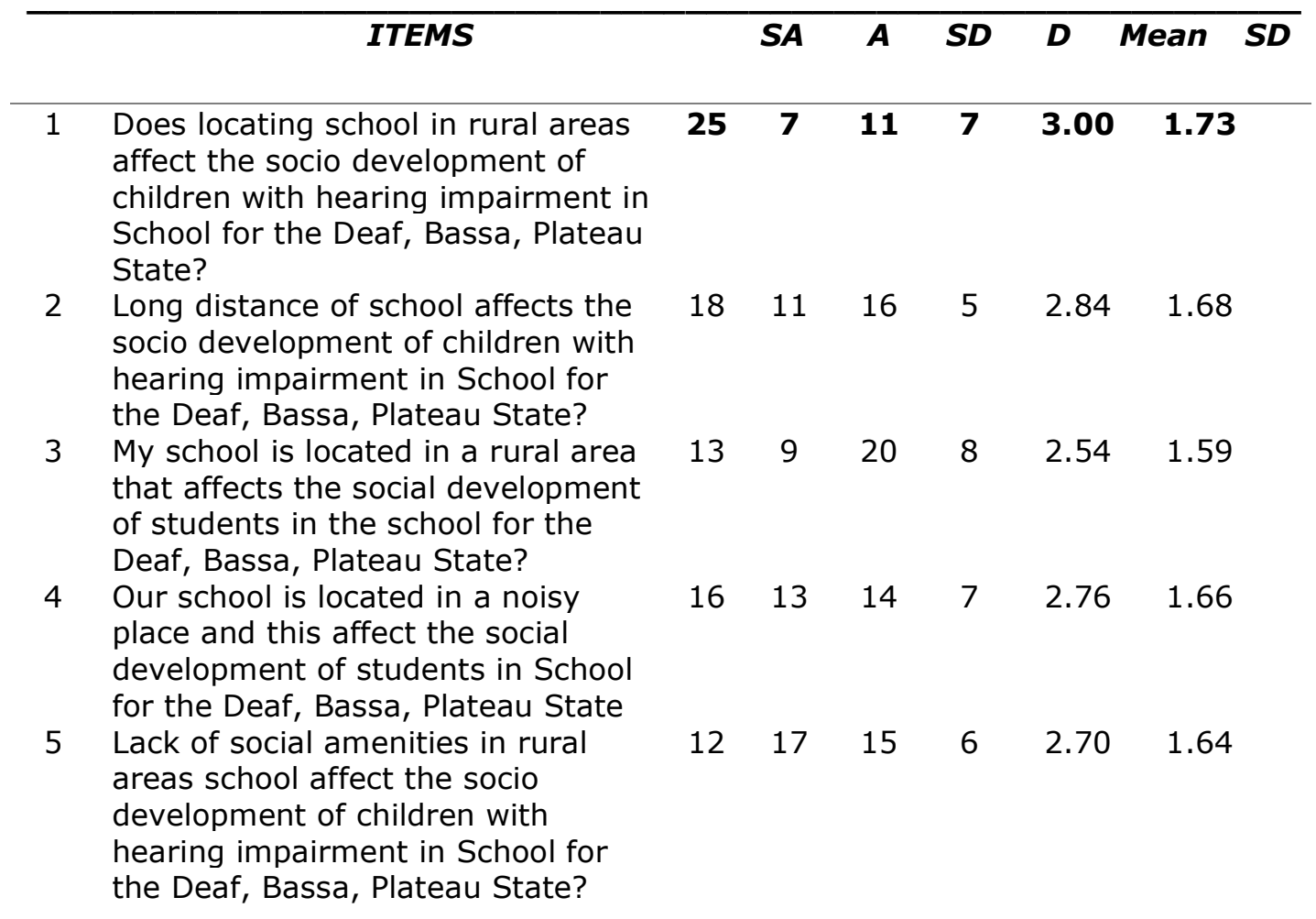

From the table 3 , Item 1 has the mean of 3.00 which is more than 2.5 and it is $t$ be accepted that locating school in rural areas affect the socio development of children with hearing impairment in School for the Deaf, Bassa, Plateau State. Item 2 has the mean of 2.84 which is more than 2.5 and it is to be accepted that long distance of school affects the socio development of children with hearing impairment in in School for the Deaf, Bassa, Plateau State. Item has the mean of 2.54 which is more than 2.5 and it is to be accepted that my school is located in a rural area which affect the social development of students in School for the Deaf, Bassa, Plateau State.
Item 4 has the mean of 2.76 which is more than 2.5 and it is to be accepted that our school is located in a noisy place and this affect the social development of students in School for the Deaf, Bassa, Plateau State. Item 5 has the mean of 2.70, which is more than 2.5 and it is to be accepted that lack of social amenities in rural areas school affect the socio development of children with hearing impairment in School for the Deaf, Bassa, Plateau State.

Research Question 4: To what extent do school facilities affect the social development of students with hearing impairment? 
Journal of Educational Research in Developing Areas (JEREDA)

Vol. 2. Issue 2, Pp. 183-195, 2021

http://www.jeredajournal.com

E-mail: info@jeredajournal.com

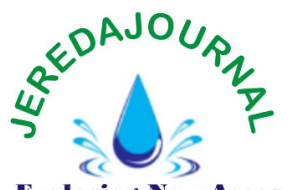

Exploring New Areas

Table 4.Analysis of the Extent of School facilities

\begin{tabular}{|c|c|c|c|c|c|c|c|}
\hline & ITEMS & & SA & $\boldsymbol{A}$ & $S D$ & $D$ & Mean \\
\hline 1 & $\begin{array}{l}\text { The poor health center in the school } \\
\text { affects the socio-development with } \\
\text { hearing impairment in Durbar School } \\
\text { for the Handicapped. }\end{array}$ & 14 & 11 & 18 & 7 & 2.64 & 1.62 \\
\hline 2 & $\begin{array}{l}\text { Insufficient and non-conducive } \\
\text { classrooms in my school in Durbar } \\
\text { School for the handicapped? }\end{array}$ & 9 & 18 & 17 & 6 & 2.60 & 1.61 \\
\hline 3 & $\begin{array}{l}\text { My school has instructional materials } \\
\text { which influence the socio } \\
\text { development of children with hearing } \\
\text { impairment at Durbar School for the } \\
\text { handicapped }\end{array}$ & 14 & 11 & 18 & 7 & 2.61 & 1.62 \\
\hline 4 & $\begin{array}{l}\text { Inadequate electricity, good roof and } \\
\text { adequate space affect the socio } \\
\text { development of children with hearing } \\
\text { impairment at Durbar School for the } \\
\text { handicapped }\end{array}$ & 13 & 21 & 13 & 3 & 2.88 & 1.69 \\
\hline 5 & $\begin{array}{l}\text { Lack of laboratory in my school affect } \\
\text { the socio development of children } \\
\text { with hearing impairment in Durbar } \\
\text { School for the handicapped? }\end{array}$ & 19 & 12 & 13 & 6 & 2.88 & 1.69 \\
\hline 6 & $\begin{array}{l}\text { There are no sufficient chairs and } \\
\text { desks in my school and this affect our } \\
\text { social development in Durbar School } \\
\text { for the handicapped }\end{array}$ & 17 & 14 & 13 & 6 & 2.84 & 1.68 \\
\hline 7 & $\begin{array}{l}\text { There is inadequate teaching staff } \\
\text { that affects the teaching of students } \\
\text { at Durbar School for the } \\
\text { handicapped. }\end{array}$ & 18 & 12 & 15 & 5 & 2.84 & 1.68 \\
\hline 8 & $\begin{array}{l}\text { There are no enough school facilities } \\
\text { in the school that affect the socio- } \\
\text { development of their students at } \\
\text { Durbar School for the handicapped }\end{array}$ & 17 & 14 & 13 & 6 & 2.84 & 1.68 \\
\hline
\end{tabular}

From the table 4 Item 1 has the mean of 2.64 which is more than 2.5 and it is to be accepted that poor health centre in the school affect the socio development with hearing impairment in School for the Deaf, Bassa, Plateau State. Item 2 has the mean of 2.60 which is more than 2.5 and it is to be accepted that there are insufficient and unconducive classrooms in my school in School for the Deaf, Bassa, Plateau State. Item 3 has the mean of 2.61 which is more than 2.5 and it is to be accepted that my school has instructional materials which influence the socio development of children with hearing impairment. in School for the Deaf, Bassa, Plateau State. Item 4 has the mean of 2.88 which is more than 2.5 and it is to be accepted that inadequate electricity, good roof and adequate space affect the socio development of children with hearing impairment in School for the Deaf, Bassa, Plateau State.

Item 5 has the mean of 2.88 which is more than 2.5 and it is to be accepted that lack of library facilities in my school affect the socio development of children with hearing impairment in School for the Deaf, Bassa, Plateau State. Item 6 has the mean of 2.84 
Journal of Educational Research in Developing Areas (JEREDA)

Vol. 2. Issue 2, Pp. 183-195, 2021

http: / /www.jeredajournal.com

E-mail: info@jeredajournal.com

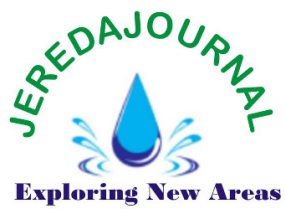

which is more than 2.5 and it is to be accepted that there are no sufficient chairs and desks in my school and this affect our social development in School for the Deaf, Bassa, Plateau State. Item 7 has the mean of 2.84 which is more than 2.5 and it is to be accepted that there is Inadequate teaching staff which affect the teaching of students in School for the Deaf, Bassa, Plateau State. Item 8 has the mean of 2.84 which is more than 2.5 and it is to be accepted that there are not enough school facilities in the school that affect the sociodevelopment of their students in the School for the Deaf, Bassa, Plateau State.

\section{DISCUSSIONS}

The findings of the study revealed that healthy and attractive school environment influence the socio development of children with hearing impairment and unconducive school environment affect the children socio development. The study is in line with (NCES, 2000) which says School buildings that can adequately provide a good learning environment are essential for student success. Old building does not have such features as control of thermal environment, adequate lighting, good roof and adequate space that are necessary for a good learning also corroborate with Earthman, 2004) which says that Older building do not have the main attribute of modern building that are associated with a positive physical environment conducive to student learning and study of (Stricherz 2000) that says Students' achievement and social development lags in a shabby or inadequate school building - those with no science labs, inadequate ventilation and faulty heating systems.

The findings of the study that on revealed that school without wellequipped library affects the sociodevelopment of children with hearing impairment in School for the Deaf, Bassa, Plateau State, Does good quality of library services affect the sociodevelopment of children with hearing impairment in School for the Deaf, Bassa, Plateau State, healthy and attractive

school environment influence the sociodevelopment of children with hearing impairment and unconducive school environment affect the socio development of children. The result of the study is in line with Keith (2000) who reports that schools with well-equipped library performs higher than schools where libraries are less developed. Libraries provide instructional materials to enrich the curriculum and give unlimited opportunities for students' learning. Also, Aguolu (2002) affirmed that effective school library provides the foundation for self-education necessary for facing the challenges of higher education and also for students' social development.

Analysis of school location on socio development the result agrees that there are not enough school facilities in the school which affect their students' socio development, does lack of social amenities in rural areas school that affect the socio development of children with hearing impairment in School for the Deaf, Bassa, Plateau State. The result is line with Ezeh (2010) who opined that school locations are known to influence the students learning through quality of teaching staff, class size and availability of infrastructure. A child's environment that is rural or urban exerts considerable influence on his intellectual development, Okonkwo (1997) pointed out that schools in rural areas are likely to face the problem of poor academic achievement due to the inequality in the provision of human and material resources required for positive educational achievement.

Analysis of school location on socio development, the result shows poor health centre in the school affect the socio development with hearing impairment in School for the Deaf, Bassa, Plateau State, and there is Insufficient and unconducive classrooms in my school in School for the Deaf, Bassa, Plateau State, and there are no sufficient chairs and desks in my school and this affect our social development in School for the Deaf, Bassa, Plateau State. The result correlates with Adeboyeje (1994) and Ayodele (2004) who pointed out that the availability of adequate chairs, desks and 
Journal of Educational Research in Developing Areas (JEREDA)

Vol. 2. Issue 2, Pp. 183-195, 2021

http://www.jeredajournal.com

E-mail: info@jeredajournal.com

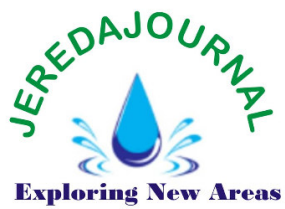

other facilities are necessary for the accomplishment of any educational goals and objectives. They revealed that effective management of school facilities brings about development of educational programmes, social development of students and facilitates educational process. It also results to boosting of the morale of teachers and students and enhances the usefulness in the determination of the worth of a school. In the same vein, Hinum (1999) reported that there is a significance relationship between students' social development and the condition of the built environment.

\section{CONCLUSION}

Children's social behaviours depend on several factors both in the human and physical environment. Classroom teachers and parents are highly contributing to children's social behaviours. A teacher who displays motherly behaviour, care, and support for his or her students, infuse positive behaviour. A good and conducive classroom will also contribute to the social development of students with hearing impairment. A teacher who inventively and creatively plan and conducts his or her teaching in a motherly manner using appropriate methods, instills positive social behaviour in the children. If a teacher uses appropriate teaching/learning materials, children will develop interest in learning and become cooperative. Advanced materials may of course cause confusion and confusion among children and as result children start developing poor social behaviour.

The quality of school building plays vital role in students' academic achievement. Since this is so, it is imperative that the government and other stakeholders in the education industry give adequate priority to solid and adequate school structures in the system. They are to ensure not only their provision, but ensure that school buildings are regularly maintained to promote durability and usage. All this will help

and enhancing the productivity level of the teachers.

The importance of good library in the education sector cannot be overemphasized. The library remains the heart of the education enterprise. As a repository of knowledge, efforts should be made to equip libraries with current materials to provide learners with more opportunities to acquire knowledge that helps facilitate high academic achievement. Qualified library assistants should also be posted to schools to ensure proper guidance and direction to students for effective use of library facilities.

Access to school is one of the areas that influence the achievement of students in public secondary schools. Thus, the site and choice of school locations should guide parents and guardians in seeking admission for their wards. This will not only ensure the influence of the child's environment, but will reduce costs, especially the burden of transportation, on parents. Therefore, policy makers must ensure adequate access to the school location for students in their areas.

\section{RECOMMENDATIONS}

1. Adequate classroom buildings to be provided in the schools to help promote effective teaching for students improved academic achievement.

2. Government and communities to ensure that students have access to the schools nearest to their areas of residence.

3. Efforts should be made by stakeholders to provide schools with functional libraries, well equipped with current reading reference materials.

4. Qualified library assistants to be posted to schools to help the students make the proper use of the library service.

5. Enough security to be provided through fencing of schools to ensure peaceful school academic environment.

6. As may be applicable, schools without power supply must be 
Journal of Educational Research in Developing Areas (JEREDA)

Vol. 2. Issue 2, Pp. 183-195, 2021

http://www.jeredajournal.com

E-mail: info@jeredajournal.com

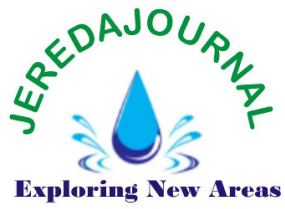

provided with generating sets to help promote effective learning in the schools.

7. Office accommodations should be provided to teachers to allow them to have appropriate space and time for their lesson notes and other related academic activities.

8. Current teaching or instructional materials to be made available to schools to help teachers perform for the best academic achievement of students in schools.

\section{Conflict of Interest}

The authors declare that they have no conflict of interest.

\section{Notes on the Authors:}

Dr. (Mrs.) Patricia Kwalzoom Longpoe holds a PhD.in Special Needs Education. She is a certified educator and a teacher. She is currently a lecturer at the Department of Special Needs Education and Rehabilitation Sciences, University of Jos, Plateau state, Nigeria. A member of the professional bodies of NAEC and NASET.

Dr. Nenrot V. Gomwalk holds a PhD. in Special Needs Education. She is a certified educationist. She is currently a lecturer at the Department of Special Needs Education and Rehabilitation Sciences, University of Jos, Plateau state, Nigeria. A member of the professional bodies of NAEC and NASET.

\section{Authors and Level of Contributions}

Dr. (Mrs.) Patricia Kwalzoom Longpoe thought up the title of the study, designed the study, wrote the introduction, purpose and compiled the manuscript. She generated the research questions and hypotheses, she did the conclusion and recommendation part.

Dr. Nenrot v. Gomwalk handled questionnaire distribution in the sample schools, compiled and arranged results collected. She handled the statistical analysis, data compilation, discussion,

compiled and arranged results collected and proof read the manuscript.

Disclaimer Statement: The authors hereby declare that this study was independently carried out by the authors and that the expressions and opinions therein are purely those of the authors and do not represent the official position of the University of Jos.

\section{REFERENCES}

Abang, T. B. (2005). Handbook of special education. Fab Educational Books.

Adeboyeje, R. A. (1994). Managing of school physical facilities. Ibadan Fountain Publication.

Afari, E. (2015). Relationships between School Climate, bullying and delinquent behaviours. Learning Environments Research, 6(3), 23-35. https://doi.org/10.1007/ s10984-017-9249-6.

Aguolu, J.(2002). Early childhood development: A multicultural perspective. 5th Edn. Merrill.

Akpa, G.O., Udoh, S.U., \& Fagbamiye, E.O. (2005). Deregulating the Provision and Management of Education in Nigeria. The Nigerian Association for Educational Administration and Planning (NAEAP).

Aldridge, J., Mcchesney, K., \& Afari, E. (2018). Relationships between school climate, bullying and delinquent behaviours. Learning Environments Research, 21(1), 120.

https://doi.org/10.1007/s10984$\underline{017-9249-6}$

Ani, M. F. (2016). Developing regression models of driver fatigue using an ergonomics approach. Unpublished master's thesis). Universiti Teknikal Malaysia Melaka. http://eprints. utem. edu. $\mathrm{my} / \mathrm{id} / \mathrm{eprint} / 18595$

Ayodele, J.B. (2004). The role of the head teachers in school plant management and maintenance. In E.O. Fagbamiye., J.B, Babaloja, M. Fabunmi \& A.O. Ayemi (Eds.), Management of Primary and 
Journal of Educational Research in Developing Areas (JEREDA)

Vol. 2. Issue 2, Pp. 183-195, 2021

http://www.jeredajournal.com

E-mail: info@jeredajournal.com

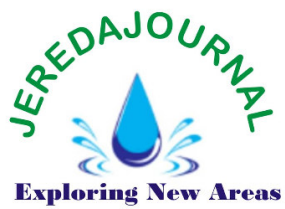

Secondary Education in Nigeria (pp.93 - 100). NAEAP.

Chike-Okoli, A. N. (2004). Educational administration and planning: Theory and practice. Shamac Publisher.

Earthman, G.I. (2004). Prioritization of 31 criteria for school building adequacy. American Civil Liberties Union Foundation of Mary Land. http:www.ac/u.md.org/atop\%20is sues/education\%reform/earthfinal $10504 \mathrm{pdf}>$.

Erol, R. Y., \& Orth, U. (2011). Selfesteem development from4 age 14 to 30 years: A longitudinal study. Journal of Personality and Social Psychology, 101(3), 607619.

Eze, F.N. (2010). Influence of school environment on academic achievement of students of public secondary school in Enugu State. www.unn.edu.ng/publications/files /images/PROJECT\%20MR. $\% 20 E Z E . p d f$

Farrel, A. D.,\& Flannery, D. J. (2005). Youth violent prevention are we there yet? Aggresion and Violent Behaviour, 11, 138-150.

Federal Ministry of Education (2004). National policy on education ( $4^{\text {th }}$ Edtion). NERDC.

Haley, S. M.,\& Baryza, M. J. (1990). A hierarchy of motor outcome assessment: Self-initiated movements through adaptive motor function. Infants and Young Children, 3(2), 1-14.

Hinum, M. (1999). Strategies for managing educational facilities. Track III of the UEF/P[EB/CAE International Symposium USA.

Hoffman, L.L., Hutchinson, C.J., Reiss, E. (2009). On improving school climate: Reducing reliance on rewards and punishment. International Journal of Whole Schooling, 5(1), 234-244.

Ikediashi, A. E. (2002). Influence of physical classroom environment on academic performance of pupils in private and public schools: A case study. African
Journal of Educational Research, 2, 11-22.

Ismail, R., Ghazalli, M.N., \& Ibrahim. N. (2015). Not all developmental assets can predict negative mental health outcomes of disadvantaged youth: A case of suburban Kuala Lumpu.

Lowerfield, R. (2013). Program evaluation of a social skills and self-advocacy program for elementaryage students with hearing loss: Training and advocacy group (TAG). Unpublished report.

Midgley, M. (2014). Social participation of children and adolescents with cochlear implants: A qualitative analysis of parent, teacher, and child interviews. Journal of Deaf Studies and Deaf Education, 16(4), 474-93.

Okeke, D. (2001). Victimisation by peers: Antecedents and long term outcomes. In K.H. Rubin \& J.B. Asendorpf (Eds.), Social withdrawal, inhibition and shyness in childhood. Erlbaum.

Okeke, M. (2003). Family and school influences in behavioural development. Journal of Child Psychology and Psychiatry, 26,349-368.

Okonkwo, S.N. (1997). Job satisfaction and the work behaviour of the Nigerian teachers. In A.N. Ndu, L.O. Ocho, \& B.S Okeke (Eds.), Dynamics of educational administration and management The Nigerian perspective. Meks Publishers Limited.

Stricherz, M. (2000). Bricks and mortar boards. Education Week 20(14), 30-32.

Torelli, L., \& Durrett, C. (1996). Landscape for learning: The impact of classroom design on infants and toddlers. Early Childhood News, 8(2), 12-17.

Turner, E., Chandler, M., \& Heffer, R. (2009). The influence of parenting styles, achievement motivation, and self-efficacy on academic performance in college students. Journal of College Student 
Journal of Educational Research in Developing Areas (JEREDA)

Vol. 2. Issue 2, Pp. 183-195, 2021

http: / /www.jeredajournal.com

E-mail: info@jeredajournal.com

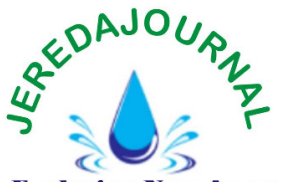

Exploring New Areas

Development, 50(3), 337-346.

https://doi.org/10.1353/csd.0.007

3.

Ugwuanyi, J.C. (2003). physical education teacher preparation in Nigeria projections and challeges. Multidisplinary Journal of Research Development, (NARD) - V) (2) $120-121$.

Umaruddin, M. (2003). The ethical philosophy of al-Ghazali. Adam Publishers.

Vuchinich, S. (1997). Parenting, peers and the stability of antisocial behaviour in pre-adolescent boys. Developmental Psychology, 28, 510-521.

Zakaria, E., Zain, N. M., Ahmad, N. A., \& Erlina, A. (2012). Mathematics anxiety and achievement among secondary school students. American Journal of Applied Sciences, 9(11), 18-28. https://doi.org/10.3844/ajass p.2012.1828.1832. 